This item was submitted to Loughborough's Research Repository by the author.

Items in Figshare are protected by copyright, with all rights reserved, unless otherwise indicated.

\title{
Art, education, and revolution: Herbert Read and the reorientation of British anarchism
}

PLEASE CITE THE PUBLISHED VERSION

http://dx.doi.org/10.1080/13825585.2012.736220

PUBLISHER

(c) Taylor \& Francis

VERSION

AM (Accepted Manuscript)

\section{PUBLISHER STATEMENT}

This work is made available according to the conditions of the Creative Commons Attribution-NonCommercialNoDerivatives 4.0 International (CC BY-NC-ND 4.0) licence. Full details of this licence are available at: https://creativecommons.org/licenses/by-nc-nd/4.0/

\section{LICENCE}

CC BY-NC-ND 4.0

\section{REPOSITORY RECORD}

Adams, Matthew S.. 2019. "Art, Education, and Revolution: Herbert Read and the Reorientation of British Anarchism”. figshare. https://hdl. handle.net/2134/22032. 


\title{
Art, Education, and Revolution: Herbert Read and the Reorientation of British Anarchism
}

\author{
Matthew S. Adams* \\ Department of History, 43 North Bailey, Durham University, Durham, \\ DH1 3EX, UK,
}

Received dates: 13/3/12 - 25/9/12 - 26/9/12

\begin{abstract}
It is popularly believed that British anarchism underwent a 'renaissance' in the 1960s, as conventional revolutionary tactics were replaced by an ethos of permanent protest. Often associated with Colin Ward and his journal Anarchy, this tactical shift is said to have occurred due to growing awareness of Gustav Landauer's work. This article challenges these readings by focusing on Herbert Read's book Education through Art, a work motivated by Read's dissatisfaction with anarchism's association with political violence. Arguing that aesthetic education could remodel social relationships in a non-hierarchical fashion, Read pioneered the reassessment of revolutionary tactics in the 1940s that is associated with the 1960s generation. His role in these debates has been ignored, but the broader political context of Read's contribution to anarchist theory has also been neglected. The reading of Read's work advanced here recovers his importance to these debates, and highlights the presence of an indigenous strand of radical thought that sought novel solutions for the problems of the age.
\end{abstract}

Keywords: Anarchism, education, pacifism, aesthetics, revolution, Herbert Read.

\footnotetext{
*E-mail: m.s.adams@durham.ac.uk
} 


\section{Introduction}

For George Woodcock, Colin Ward’s work Anarchy in Action (1973) was one of the 'most important theoretical works on the subject' of anarchism. As the 1990s dawned and European Communism crumbled with 'surprisingly little violence' in the face of 'popular movements...undirected by...any parties', Woodcock felt that Ward’s book would have a 'very great bearing' on the future course of anti-state struggles. For Woodcock, Anarchy in Action, and the material in the influential journal Anarchy that Ward edited between 1961 and 1970, represented a highly original contribution to anarchist theory, and had led to a fundamental shift in anarchist tactics. This new anarchism defined itself against an anarchist past redolent of bombs and barricades, and suggested that:

There was no need to wait for the great day of revolution, the apocalyptic moment...What we should do..[is]...to recognize how far in society anarchistic relationships actually exist, and to begin now to build on those relationships, nourishing and encouraging voluntary initiatives based on mutual aid...distinct from official initiatives. ${ }^{1}$

Writing a few years before his death, Ward expanded this vision by suggesting that anarchism had been an insidiously inspirational force in the twentieth century. ${ }^{2}$ The power of this argument helped convince Woodcock to amend his elegiac conclusion of anarchism's prospects in the 1986 reprint of his influential text Anarchism: A History of Libertarian Ideas and Movements, and to comment that the liberation of anarchists from their millennialism had sparked an intellectual 'renaissance'. ${ }^{3}$ In Ward's view, the key was not to lament anarchism’s grand failures, but to consider how creatively piecemeal action might secure a fairer society. 'While the anarchists have made little progress towards...large-scale changes in society', he

\footnotetext{
${ }^{1}$ George Woodcock, Anarchism and Anarchists: Essays (Kingston, ON, 1992), .231, 138.

${ }^{2}$ Colin Ward, Anarchism: A Very Short Introduction (Oxford, 2004), 74.

${ }^{3}$ George Woodcock, Anarchism: A History of Libertarian Ideas and Movements (London, 1986); 412. George Woodcock, Anarchism: A History of Libertarian Ideas and Movements (London [1970] 1962), 443.
} 
wrote, 'they have contributed to a long series of small liberations that have lifted a huge load of human misery'. ${ }^{4}$

This self-image of 'pragmatic', 'pragmatist' or 'practical' anarchism has led several commentators to discern a clear break with the historical tradition of anarchism. ${ }^{5}$ For Woodcock, the ideas associated with the journal Anarchy betrayed a confident 'escape [from]...doctrinaire loyalty to the historic movement' ${ }^{6}$ Similarly, David Stafford writes that pragmatic anarchism denoted a ‘departure from classical anarchism’ in its promotion of 'permanent protest' over the notion of a cathartic battle with the state. ${ }^{7}$ Whilst presented as a product of the 1960s, most commentators identify this tactical reorientation stemming from a growing familiarity with a thinker killed by the Freikorps in 1919: Gustav Landauer. ${ }^{8}$ In spite of his premature death, the enduring narrative is that Landauer's romantically tinged socialism, which saw 'the State as a set of relationships...rather than...some mechanical superstructure', proved universally persuasive in the context of the 1960s 'counter-culture'. Apparently corroborating this influence, Landauer's dictum that 'the State is a condition, a certain relationship between human beings, a mode of behaviour; we destroy it by contracting other relationships, by behaving differently', was persistently repeated in Ward’s Anarchy. ${ }^{10}$ For Ward, Landauer’s tragic legacy, was testament to a revolution that had been 'wrecked in violence and politics', a sign that successful social change could only be secured through

\footnotetext{
${ }^{4}$ Ward, Anarchism, 74.

${ }^{5}$ For these terms, see respectively: David Stafford, ‘Anarchists in Britain Today’, in Anarchism Today, edited by David E. Apter and James Joll (London, 1971), 91; Stuart White, 'Making anarchism respectable? The social philosophy of Colin Ward’, Journal of Political Ideologies, 12 (2007), 11-28 (12); Ruth Kinna, Anarchism: A Beginner's Guide (Oxford, 2005), 142-7.

${ }^{6}$ Woodcock, Anarchism (1986), 385.

${ }^{7}$ Stafford, 'Anarchists in Britain', 93. Alongside Stafford's piece, many articles in the excellent edition of the journal Anarchist Studies devoted to Ward make this case. In particular, consider: Carl Levy, 'Introduction: Colin Ward (1924-2010)', Anarchist Studies, 19 (2011), 7-15; Peter Marshall, 'Colin Ward: Sower of anarchist ideas', 16-21.

${ }^{8}$ Eugene Lunn, Prophet of Community: The Romantic Socialism of Gustav Landauer (Berkeley ,CA, 1973$), 3$.

${ }^{9}$ Peter Marshall, Demanding the Impossible: A History of Anarchism (London, 1993), 415.

${ }^{10}$ Landauer quoted in Lunn, Prophet of Community, 226; David Goodway, Anarchist Seeds Beneath the Snow: Left-Libertarian Thought and British Writers from William Morris to Colin Ward (Liverpool, 2006), 319.
} 
'rebellion and negation' and not by political action. ${ }^{11}$ The frequency with which Landauer's work was invoked in the pages of Anarchy, and subsequently in historical commentaries on British anarchism, has led, however, to more local influences on this revision of anarchist principles being obscured. ${ }^{12}$

The present article contests this reading by focusing on the work of Herbert Read, a figure that tends to be marginalised even in histories of anarchism. ${ }^{13}$ Thirty years older than Ward, the factotum public intellectual Read, one time poet, art critic, literary critic and educational philosopher, straddled the senescence of the older tradition of British anarchism and the birth of the new. Read's politicisation at the hands of the fragmentary pamphlet literature of nineteenth-century socialism as he dodged bullets in the trenches, and his post-war reputation as an intellectual trendsetter, means that his thought occupies a crucial liminal space between the old and the new. ${ }^{14}$ Looking to Read's work in the realm of educational theory, in particular his self-consciously libertarian text Education through Art (1943), shows that the fundamental assumptions that defined the later course of British anarchism, were key components of Read's ideas on aesthetic education. Although Read's educational theory has

\footnotetext{
${ }^{11}$ C.W., 'Gustav Landauer’, Anarchy, 54 (August, 1965), 244-252 (248, 247)

${ }^{12}$ For narratives emphasising Landauer’s importance, consider: Goodway, Anarchist Seeds, 318-9; Marshall, Demanding the Impossible, 415; Stafford, 'Anarchists in Britain Today', 92; Woodcock, Anarchism, 420-1.

${ }^{13}$ The closing chapter of Crowder's work on the 'classical tradition', that comments on contemporary developments in anarchist theory, mentions Murray Bookchin and Colin Ward, but not Read. See: George Crowder, Classical Anarchism: The Political Thought of Godwin, Proudhon, Bakunin, and Kropotkin (Oxford, 1991), 194-196. David Goodway’s book goes some way to correcting this lacuna, but his ultimate view is that Read was not a significant thinker, and that his role was that of conduit between the classical tradition and the modern anarchism of Bookchin and Ward. See: Goodway, Anarchist Seeds, 189. Similarly, Marshall gives Read some space, but deems him 'no original thinker'. See: Marshall, Demanding the Impossible, 587-593 (592). Woodcock's amended edition of Anarchism mentioned Read, but gave him a marginal position. That he also wrote a comprehensive intellectual biography of Read, suggests that Woodcock saw his importance less in terms of an anarchist thinker, and more in terms of his cultural theories, thus introducing an unnecessary division between these spheres of Read's work. See: Woodcock, Anarchism (1986), 382-4; George Woodcock, Herbert Read: The Stream and the Source (London, 1972). For other texts in which Read is marginalised, consider: April Carter, The Political Theory of Anarchism (London, 1971), 91-3; Benjamin Franks, Rebel Alliances: The Means and Ends of Contemporary British Anarchisms (Edinburgh, 2006), 52; David Miller, Anarchism (London, 1984) 141-151.

${ }^{14}$ Read is the most interesting, if not necessarily the most trustworthy, guide to his political development. See: Herbert Read, The Contrary Experience: Autobiographies (London, 1963), 70-146; 255-281. For a debate on this topic see: David Goodway, 'Herbert Read, organicism, abstraction and an anarchist aesthetic' and Alan Antliff, 'David Goodway critiques Herbert Read', Anarchist Studies, 19, No.1 (2011), 82-106.
} 
attracted attention, and has occasionally been recognised as a component of his anarchist philosophy, the origin of these ideas in his disenchantment with conventional explanations of revolutionary transformation has been ignored. ${ }^{15}$ Indeed, a lacuna in the recent growth of literature exploring Read's ideas is the lack of attention paid to reconstructing the context in which his philosophy grew. ${ }^{16}$ Twenty-years prior to anarchism’s ‘60s resurgence, Read’s scepticism regarding conventional revolutionary tactics encouraged him to theorise the journey from capitalism to communism afresh.

The first section of this article makes a case for the importance of contextually robust intellectual history, by charting Read's developing disenchantment with anarchist tactics against a backdrop of war and official repression of dissent. Although often portrayed as a lifelong pacifist, a position stemming from his experience in the Great War, Read in fact had an ambiguous relationship to the question of violence. His initial hostility to the Second World War softened as he came to believe that there were British liberties worth defending, and Read's early hope that international conflict might lead to domestic revolution would be qualified. During this tumult, however, Read began to reflect on anarchism’s revolutionary heritage, and, uniting his aesthetic concerns with a belief in the redemptive powers of education, wrote Education through Art. ${ }^{17}$ Having concluded that education should displace

\footnotetext{
${ }^{15}$ Francis Berry, Herbert Read (London, 1961), 9; Sam Black, 'Herbert Read: His Contribution to Art Education and to Education through Art', in Herbert Read: A Memorial Symposium, edited by Robert Skelton (London, 1969), 57-65; Goodway, Anarchist Seeds,196-197; Marshall, Demanding the Impossible, 588; Michael J. Parsons, 'Herbert Read on Education', Journal of Aesthetic Education, 3 (Oct., 1969), 27-45; Malcolm Ross, 'Herbert Read: Art, Education, and the Means of Redemption', in Herbert Read Reassessed, edited by David Goodway (Liverpool, 1998), 196-214; Woodcock, Herbert Read, 264-281.

${ }^{16}$ Dana Ward, 'Art and Anarchy: Herbert Read's Aesthetic Politics', in ReReading Read: New Views on Herbert Read, edited by Michael Paraskos (London, 2007), 20-33. Carissa Honeywell's recent book goes some way towards addressing this issue, but it is not primarily intended as an historical work, and the context of Read's ideas remains somewhat underdeveloped. See: Carissa Honeywell, A British Anarchist Tradition: Herbert Read, Alex Comfort and Colin Ward (London, 2011). Allan Antliff also shows sensitivity to the context of Read's aesthetics, see: Allan Antliff, 'Open form and the abstract imperative: Herbert Read and contemporary anarchist art’ Anarchist Studies, 16 (2008), 6-19

${ }^{17}$ Art education had been a relatively early interest for Read, and his inaugural address as Professor of Fine Art at the University of Edinburgh, delivered in 1931, was titled 'The Place of Art in a University'. This text is reprinted in: Herbert Read, Education through Art (London, 1943), 251-258.
} 
revolution in the anarchist arsenal during the war, the trial and imprisonment of a group of anarchists associated with the journal War Commentary in 1945 cemented Read's position on the fallacy of violent revolution. Although the tendency has been to see the trial as a boon for anarchism in Britain, as heightened awareness swelled the ranks and the Freedom Defence Committee attracted a host of prominent intellectual supporters, the conclusion here is quite different. What the imprisonment of the War Commentary anarchists revealed in fact was the enduring strength of the state, with the subsequent rapid demise of the Defence Committee proving a stern lesson in the power of British anarchism.

The second section of this article shifts from the book's genesis to its relevance as a contribution to anarchist theory, and particularly the anarchism that was to develop in Britain in the 1960s. For Read, writing in the war years, aesthetics offered a solution to the barbarity of the age. At the heart of this aesthetic project was a political impulse that saw an anarchist society as the only viable crucible for individual development. Yet, in the context of Nazi attacks on culture and the grinding war of attrition in the East, Read's message gained a note of harried urgency. Whilst prone to grandiloquence, his wartime writing began to describe the future path of humankind in starker terms. He decried the 'mass insanity', the 'mass renunciation of reason' that had engulfed 'Europe and Asia, Africa and Australia, and now spreads to America', a universal 'Bedlam' that risked tipping the world towards the precipice. ${ }^{18}$ As international conflict gave way to the threat of nuclear obliteration this timbre was to remain in Read's work. The themes that define Education through Art therefore go to the very heart of Read's politically charged aesthetics. Having explored the book's context and content, the concluding section seeks to understand Read's legacy in terms of anarchist history, and British intellectual history more generally. The argument here is that in

\footnotetext{
${ }^{18}$ Herbert Read, 'Bedlam Politics [1941]' in Herbert Read: A One-Man Manifesto and Other Writings for Freedom Press, edited by David Goodway (London, 1994), 61-64 (63).
} 
formulating this fresh politics in response to war and in reaction to anarchism's past, Read both pre-empted and would inform the emergence of pragmatic anarchism in the 1960s. His work, therefore, is an unduly overlooked aspect of this moment in anarchism's intellectual history. Yet, he is also an unfairly forgotten figure in British intellectual and cultural history more generally, as is the indigenous strand of anarchist thinking that he represented. Despite theoretical inadequacies and inconsistencies, Read's idiosyncratic politics signify a tradition of political thinking that was to undergo an intellectual renaissance, as the inherited values of the nineteenth-century were rethought in the twentieth. ${ }^{19}$ Negotiating this relationship, Read was engaged in constructing a novel set of political values that would contribute to the added urgency of British anarchism in the 1960s.

\section{The Context of Education through Art: Revolution, Pacifism, and Pessimism}

Writing on the theme of 'Anarchism: Past and Future' in 1947, Read betrayed the fact that his anarchism centred on a critical dialogue with the past. Reflecting on the need for anarchists to build a coherent philosophy in tune with contemporary intellectual trends, Read paused to address the objection that this might 'suggest the rigid structure of a universal philosophy on the lines of Comte or Herbert Spencer. ${ }^{20}$ On the contrary, he argued, anarchist philosophy must 'allow...for growth, for variation, for the possibility of new dimensions of personal development' of which the Procrustean system-builders were oblivious. Although rejecting the past, Read's call for a 'scientific' and 'consistent' investigation of anarchist philosophy mirrored that of Peter Kropotkin, the intellectual giant of nineteenth-century anarchism, who frequently emphasised the need for anarchism to adopt the epistemological precepts of modern science. In this vein, Kropotkin too was an advocate, but also a compelling critic, of Comte and Spencer's systematic philosophy, commending their analytical astuteness, but

\footnotetext{
${ }^{19}$ For personal inconsistencies, see: Goodway, Anarchist Seeds, 200- 201; Honeywell, A British Anarchist Tradition, 54.

${ }^{20}$ Herbert Read, ‘Anarchism: Past and Future [1947]' in A One-Man Manifesto, 117-125 (124).
} 
sceptical of the political conclusions that both thinkers drew. ${ }^{21}$ By urging anarchists to turn with alacrity to the history of civilisations, anthropology, and psychology, Read was therefore repeating a familiarly Kropotkinian refrain. ${ }^{22}$ Yet, at the same time 'Anarchism: Past and Future' shows Read salvaging certain aspects of the anarchist edifice, whilst consigning much of its tactical heritage to the dustbin. Conscious, perhaps, of offending the sensibilities of pious comrades, Read did not implicate Kropotkin in his rejection of anarchism's revolutionary history, choosing instead to present himself as Kropotkin’s ideological heir. 'We have to go on from the point where Kropotkin left off', he said, and a defining aspect of this intellectual journey was a rejection of a violent confrontation with the state:

The revolution envisaged is a humane one...If we can secure a revolution in the mental and emotional attitudes of men, the rest follows... It discards forever the romantic conception of anarchism - conspiracy, assassination, citizen armies, the barricades. All that futile agitation has long been obsolete...The real revolution is internal...the most effective action is molecular. ${ }^{23}$

Read's view stood in distinction to the dominant strand in the historical tradition of anarchism, which generally looked forward to a cataclysmic sweeping away of the state. Revolutionary activity should be directed toward this end, whether through direct confrontation with the agencies of the state, or, when anarchism was weak, with patient propagandising to stimulate critical consciousness amongst the workers. ${ }^{24}$ Read pursued a different vision of social change, writing that 'the word revolution should...disappear from our propaganda, to be replaced by the word education. ${ }^{25}$ Reflecting his developing interest in the work of Landauer and the Jewish philosopher Martin Buber, who was one of Landauer's chief-popularisers in radical-literary circles, Read fused this conception of revolutionary

\footnotetext{
${ }^{21}$ Peter Kropotkin, 'Modern Science and Anarchism', in Evolution and Environment, edited by George Woodcock (Montréal, [1912] 1995), 15-107 (31-34).

${ }^{22}$ Read, 'Anarchism: Past and Future', 118-120.

${ }^{23}$ Read, 'Anarchism: Past and Future', 124.

${ }^{24}$ For a classic statement of this view, consider: Peter Kropotkin, 'Glimpses into the Labour Movement in this Country’ in Freedom: A Journal of Anarchist Communism (Oct., 1907).

${ }^{25}$ Read, 'Anarchism: Past and Future', 122.
} 
change with a belief in 'non-violence - in non-violent resistance to oppression, and in nonviolent methods of attaining our ends. ${ }^{26}$

In reaching this position that emphasised the tactical efficacy of non-violence, Read's thought had followed a meandering path, defined by an inconsistent approach to the legitimacy of war. Whilst several commentators, including some of his most vocal critics, focus on Read's pacifism as a rare island of consistency in a career otherwise characterised by vacillation, the reality is more complicated. ${ }^{27}$ By the time that he came to reflect on anarchism's future prospects in 1947, Read had shifted to a recognisably pacifist position, and one that would harden once Ghandian ideas became influential in the peace movement of the 1950 s. ${ }^{28}$ Read had recognised the significance of Mohandas Ghandi as early as 1943, but sounded a note of scepticism over his 'tactical compromise... with the...leaders of the Congress Party'. Gandhi's message remained 'insistent...and directly applicable', but the purity of ahimsa was tainted by this concession to organised politics. ${ }^{29}$ Read's equivocation in 1943 over Ghandian tactics was matched by inconsistency over the legitimacy of war. Although often identified as an inveterate critic of war, a position heavily influenced by his own experiences in the trenches, Read's self-ascription of the label 'pacifist' in the wake of the Great War is misleading. ${ }^{30}$ In Poetry and Anarchism (1938) Read adopts a position closer to A.J.P. Taylor's useful term 'pacificism', understood as an opposition to war rather than violence in toto. ${ }^{31}$ Yet, Read's conviction that war was a product of statism, and that 'non-governmental society’ was the sole cure, did not lead to a consistent position once Britain became

\footnotetext{
${ }^{26}$ Read, 'Anarchism: Past and Future', 118.

${ }^{27}$ Goodway, Anarchist Seeds, 189-90; Honeywell, A British Anarchist Tradition, 56-7; Nicolas Walter, 'Remembering Herbert Read', Anarchy, 91 (Sept., 1968), 287-288 (288).

${ }^{28}$ Richard Taylor, Against the Bomb: The British Peace Movement: 1958-1965 (Oxford, 1988), 116-8.

${ }^{29}$ Herbert Read, The Politics of the Unpolitical (London, 1943), 2,3.

${ }^{30}$ Herbert Read, Poetry and Anarchism (London, 1938), 102; Honeywell, A British Anarchist Tradition, 56-7.

${ }^{31}$ A.J.P. Taylor, The Trouble Makers: Dissent Over Foreign Policy, 1792-1939 (London, [1957] 1993), 51n;

Read, Poetry and Anarchism, 116.
} 
embroiled in a fresh imbroglio in $1939 .{ }^{32}$ Mirroring George Orwell’s assessment of the situation, Read came to the conclusion that there were British liberties worth protecting. ${ }^{33}$ Pondering the joys of Britain’s elegiac poetry and its romantic landscape painting, he concluded that these uniquely British cultural traditions were reason enough for fighting. 'We are fighting this war', he wrote boldly, 'precisely because in these respects we refuse to be changed.' 34

Read's bombastic call to protect British culture and his concession that the war was worth fighting, highlight the shifts that his thought underwent before he reached the position expounded in his 1947 article rejecting anarchism’s revolutionary heritage. Significantly, however, Read's gradualist tactics developed against the backdrop of war, and in reaction to the increasing role of the state in social life. Whilst wartime restrictions made this involvement explicit, the arrest in 1944 of four contributors to the anarchist periodical War Commentary, and Read's participation in their defence, brought home the state's newfound dominance. Initially however, Read believed that the war might create new possibilities for social liberation: first by sparking revolution, and later in the post-war reconstruction of Europe. Indeed, two months after Operation Overlord had begun, and plans for the rebuilding of Europe were being discussed in earnest, Read expressed vexation in the columns of The Spectator that a 'third way' was being neglected. 'You pose the ineluctable alternative of monopoly capitalism or State socialism', he wrote, 'once more you display an obstinate disregard of...libertarian socialism'. Rather than being impelled towards adopting statism on either an American or Soviet model, Read suggested that if 'Italy and Poland...free Spain and even...France....are ...left to themselves' they may 'evolve communities of self-governing

\footnotetext{
${ }^{32}$ Read, Poetry and Anarchism, 120.

${ }^{33}$ Consider: George Orwell, 'Pacifism and the War: A Controversy [1942]', in The Complete Works of George Orwell: Volume Thirteen: All Propaganda is Lies: 1941-42 (London, 1998), 396-400.

${ }^{34}$ Herbert Read, 'The War as Seen by British Artists', in Britain at War, edited by Monroe Wheeler (New York, [1941] 1972), 11-12 (12).
} 
industries' underpinned by 'mutual aid’ ${ }^{35}$ A year later, Read confessed that his presentiment that war would induce social revolution was misplaced:

There was a time - back in 1940 - when I thought that here too war would inevitably lead to revolution - that it would be neither won nor lost without a social upheaval. I was wrong. We won the Battle of Britain, but lost the chance of a British Revolution. ${ }^{36}$

This mea culpa came in a speech delivered after the imprisonment of anarchists Vernon Richards, John Hewetson, and Philip Sansom in April 1945, on the charge of endeavouring 'to seduce members of the forces from their duty'. ${ }^{37}$ On the $12^{\text {th }}$ December 1944 , Special Branch officers raided the offices of the anarchist-publishing house Freedom Press, which had been printing the newspaper War Commentary since the autumn of $1939 .^{38}$ The prosecution homed in on one article entitled 'People Under Arms', which stated that, 'the duty of anarchists is to urge...workers everywhere, as Connolly did...to hold onto their arms. While the workers have weapons in their hands Governments are weak.' Similarly, a circular encouraged soldiers to establish 'discussion groups', on the reasoning that these may ultimately 'form the basis of future soldiers' councils in a revolutionary situation. ${ }^{39}$ There was a strong outcry in certain circles that their arrest and subsequent imprisonment amounted to a curtailment of basic liberties - a view strengthened by the assumption that Allied victory seemed assured by $1944 .{ }^{40}$ The Freedom Defence Committee was established in the same year to draw attention to the case, chaired by Herbert Read and attracting a galaxy of British

\footnotetext{
${ }^{35}$ Herbert Read, 'What is Freedom?' in The New Statesman, $26^{\text {th }}$ August 1944, 137.

${ }^{36}$ Herbert Read, Freedom: Is It A Crime? Two Speeches by Herbert Read (London, 1945), 6.

${ }^{37}$ 'Forces Seduction Conspiracy: Three Men Sent to Prison' in The Manchester Guardian, 27 ${ }^{\text {th }}$ April, 1945, 3; Herbert Read, Freedom Is It a Crime? The Strange Case of the Three Anarchists Jailed at the Old Bailey, April 1945: Two Speeches by Herbert Read (London, 1945). The charges against the fourth defendant, Marie Louise Berneri, were dropped on the basis that, under British law, a wife could not be prosecuted for conspiring with her husband. See: Goodway, Anarchist Seeds, 144.

${ }^{38}$ For an interesting account of the trial, and particularly Ward's involvement, see: Pietro Di Paolo, “The man who knows his village' Colin Ward and Freedom Press', Anarchist Studies, 19, No.2 (2011), 22-41.

${ }^{39}$ Quoted in 'Duty of Anarchists: Article Leads to Prosecution' in The Manchester Guardian, $10^{\text {th }}$ March, 1945, 3. See also: 'Attempt to Cause Disaffection: Four Persons on Trial at Old Bailey' in The Times, $24^{\text {th }}$ April, 1945, 2 .

${ }^{40}$ For a useful discussion, see: Honeywell, A British Anarchist Tradition, 15-16.
} 
intellectual opinion from E.M. Forster and Bertrand Russell to Julian Huxley and Henry Moore. ${ }^{41}$ After the trial, the Committee mutated into a more general agency to defend those 'penalised for exercising their rights to freedom of speech, writing and action', and its Constitution defined its means of activity as 'publicity through protest meetings, articles and letters to the press...[with]...legal... aid given when necessary and possible. ${ }^{42}$

The emergence of the Defence Committee is often placed in a triumphalist narrative of British anarchism, where the conscience raising activities of the group and its practical focus are portrayed leading to a general renewal of anarchist politics. ${ }^{43}$ Although there is much to be said for this view, a less optimistic assessment helps explain why Read's approach to social change, hitherto inconsistent, began to solidify. Intellectual opinion may have railed against the trial, but ultimately, the outrage neatly mirrored Woodcock’s description of 'English anarchism' as a 'chorus of voices crying in the wilderness.' ${ }^{44}$ The Committee failed, and three of the defendants were imprisoned. In a 1948 letter to Victor Gollancz, Read sounded a pessimistic note concerning the organisation, suggesting that there was 'something fundamentally wrong with the Committee as at present constituted'. He even suggested that its sluggishness was partly his fault:

The Committee needs a more dynamic management. I am not a good Chairman from any point of view - I have too many committees (eight or nine, chairman of four) and apart from lack of time and energy, I don't think I know how to attract the right kind of people to our support. ${ }^{45}$

\footnotetext{
${ }^{41}$ See: Goodway, Anarchist Seeds, 143-4. For a list of members, see: Read, Freedom: Is It a Crime?, 14.

42 'Freedom Defence Committee Constitution', Herbert Read Archive, University of Victoria, Box 7, File 11: $50 / 1$.

${ }^{43}$ For this narrative, consider: Honeywell, A British Anarchist Tradition, 53-55.

${ }^{44}$ Woodcock, Anarchism (1972), 414.

${ }^{45}$ Herbert Read to Victor Gollancz, $24^{\text {th }}$ December 1948, Herbert Read Archive, University of Victoria, B7 F11: Unnumbered.
} 
The following year the Committee disbanded. ${ }^{46}$ Similarly, the argument that 'the anarchists found...their profile' raised by the attention of 'the high distribution daily tabloids', does not bear up to scrutiny. ${ }^{47}$ The tabloid Daily Mirror, by this time broadly left leaning, did not mention the trial, and even though the sympathetic Manchester Guardian gave it coverage, it was usually relegated to the 'Letters to the Editor' section. The physical space given to articles commenting on the trial in the newspapers also implies general indifference. ${ }^{48}$ Reports of the trial in The Times, admittedly hardly a bastion of socialist comment, found it sandwiched between a piece on American soldiers' celebration of Shakespeare’s birthday, and Winston Churchill's attendance at the Parliamentary Press Gallery Luncheon. ${ }^{49}$ In the same vein, and continuing the culinary theme, an austere letter in the Manchester Guardian from the Committee, found itself placed against a missive from Dr J.E. Judson of Bournemouth, deploring the detrimental health effects of white bread, and proposing that a doctor's certificate should be necessary for its procurement. ${ }^{50}$ There was little reason for optimism here, and Read's post-trial comments demonstrate a revised approach to revolution cognisant of the present political climate. Although he urged those whose countries' regimes tottered - ‘France, Belgium, Italy, Greece, and now Germany’ - to retain their arms lest new 'gangsters...organize another State', his vision for Britain was more pragmatic. Parodying Churchill's famous speech of 1940, Read imagined a very different terrain for domestic political struggles:

[The] fight will not be conducted in the hills or on the beaches or in any such romantic places - it will be carried into the streets and docks, into slums and factories. Nor shall we fight with block-busters and tanks, not even with tommy-

\footnotetext{
${ }^{46}$ Goodway, Anarchist Seeds, 143.

${ }^{47}$ Honeywell, British Anarchist Tradition, 54.

${ }^{48}$ The opposite, in effect, of the 'proliferation of meaning'. Judith R. Walkowitz, City of Dreadful Delight: Narratives of Sexual Danger in Late-Victorian London (Chicago, 1992), 85. I am indebted to Eloise Moss for this reference.

${ }^{49}$ See: 'Shakespeare’s Birthday' and 'Mr. Churchill at Press Gallery Luncheon', The Times, 24 ${ }^{\text {th }}$ April 1945, 2.

50 'White Bread' in Manchester Guardian, $27^{\text {th }}$ February 1945, 4.
} 
guns and bombs. Our weapons are words, and all we need for success is freedom of speech and expression. ${ }^{51}$

Earnest propaganda was now the key. As the establishment flexed its muscle, the 'romantic' conception of revolution had passed, to be resolutely 'blown into oblivion by the atom bomb' on $6^{\text {th }}$ August $1945 .^{52}$ Anarchists must think afresh about how to secure anarchism.

\section{Education through Art as an Anarchist Contribution}

But Read had already begun to think again about how a libertarian society might be achieved. In 1945 he may have pointed to the efficacy of the book over the tommy-gun, and in 1947 he might have dismissed the 'romantic' belief in barricades and dynamite, but as early as 1943 Read had already published his own contribution to the debate over tactics. Appointed to a fellowship at the University of London between 1940 and 1942, Read sat imperviously writing a treatise on educational ideas as the Battle of Britain raged in the sky above him. The contrast could be bathetic if the book that emerged from this period of intense activity, Education through Art, had simply insisted on the moral superiority of aesthetic education. Yet, Read was not oblivious to contemporary attacks on culture. Quoting Hanns Johst's (in)famous statement, 'when I hear the word culture, I release the safety-catch on my Browning', Read lampooned the 'simple-minded and slow-witted' Nazis for 'being satisfied... behind their bombers and brass-bands' as they heaped books on the bonfires of the Opernplatz. ${ }^{53}$ Read might have posed as the iconoclast crying 'to hell with culture!', but his solution was not cultural barbarism. ${ }^{54}$ On the contrary, he argued that the Nazis singularly failed to realise the futility of attempting to affect change in the cultural realm, while the iniquitous social relations caused by capitalism remained intact. They 'hate the sauce on the stale fish, and they prepare to change it', Read jocularly wrote, 'but to change the sauce, not

\footnotetext{
${ }^{51}$ Read, Freedom: Is It A Crime?, 11, 7.

${ }^{52}$ Read, 'Anarchism: Past and Future', 124.

53 Read, The Politics of the Unpolitical, 50.

${ }^{54}$ Read, The Politics of the Unpolitical, 49.
} 
the fish! ${ }^{55}$ Against this backdrop, Read's quest for an organic culture growing freely from a rejuvenated social life acquired an added note of urgency - even if his utopia appeared all the more remote.

In turning to the redemptive powers of education as the key to overcoming capitalism, Read was acting within a rich seam of thought. Fittingly given Read's lifelong prejudice for the romantics, nineteenth-century socialists often invested their alternative models of education with a romantic inflection, manifest in a belief that emancipation from capitalism would also necessarily entail a spiritual and ethical manumission. ${ }^{56}$ There is a clearer line of influence between Read and another English romantic, similarly seeking to develop a socialist theory of art: William Morris. For Morris, as for Read forty-years later, education had a transformative power that might usher in socialism. The strength of this conviction is attested by the fact that when Morris was busy propagandising for the Democratic Federation, he placed education at the forefront of the socialist armoury:

Educate, Agitate, Organize; these words the motto of our Federation do most completely express what is necessary to be done by those who have any hope in the future of the People. ${ }^{57}$

Given Read's obvious interest in aesthetics, it would be tempting to draw a direct line of influence between the two. In fact, not only was Morris’ education programme a modest one in comparison to Read's quest for a universal sensitivity to aesthetics, but Read had an ambiguous relation to Morris. ${ }^{58}$ While Read identified Morris as an important influence on his personal road to socialism, early on in his first political pamphlet, he confessed that, despite his antipathy to the present 'industrialism...I am no yearning medievalist, and have

\footnotetext{
${ }^{55}$ Read, The Politics of the Unpolitical, 50.

${ }^{56}$ Mark Bevir, The Making of British Socialism (Princeton, 2011), 246, 242.

${ }^{57}$ William Morris, 'Art and the People: A Socialist’s Protest Against Capitalist Brutality; Addressed to the Working Classes [1883]', Art and Society: Lectures and Essays by William Morris, edited by Gary Zabel (Boston, 1993), 43-62 (62).

${ }^{58}$ For a useful discussion of Morris’ educational ideas, see: Ruth Kinna, William Morris: The Art of Socialism (Cardiff, 2000), 172-177.
} 
always denounced the sentimental reaction of Morris and his disciples. ${ }^{59}$ Indeed, Read never mentioned Morris’ educational approach to socialism, concentrating instead on exploring the ramifications of his aesthetic vision. In this area, he continued to be critical of his intransigence on the issue of machinery - despite observing that Morris later modified his attitude. ${ }^{60}$ For Read, adding an aesthetic dimension to Kropotkin's faith in technological progress, the machine age did not necessarily entail the destruction of beauty, and he suggested that, 'these days', Morris would be 'reconciled to the inevitability of machinery'. ${ }^{61}$

If Read was only influenced by Morris’ educational ideas indirectly, a stronger connection can be seen in the work of A.R. Orage, Read's de facto mentor. ${ }^{62}$ Read began to write for Orage’s influential journal New Age after avidly reading it during the war, and through this reading he would have encountered frequent reflections on the status of education. In March 1917, with Read stationed at a military camp in Staffordshire shortly to return to France, Orage published, under his pseudonym R.H.C., a mildly critical review of Kenneth Richmond's primer The Permanent Values in Education (1917). Observing that Richmond's book, which collected the lessons of previous educational philosophers, was a welcome addition, Orage voiced scepticism at the relevance of these teachings:

I cannot get away from the feeling that if Pestalozzi and all the rest have been abandoned after only a brief working of their quarries, the reason is something more than our modern idleness; it is, perchance, that the prospects opened up by these pioneers have not the attraction to keep us exploiting them. ${ }^{63}$

\footnotetext{
${ }^{59}$ Read, Contrary Experience, 200-201; Read, Poetry and Anarchism, 9.

${ }^{60}$ Herbert Read, Art and Industry: The Principles of Industrial Design (London, [1934] 1944), 42. On Morris' views of the machine, consider: William Morris 'How We Live and How We Might Live', in Political Writings of William Morris, edited by A.L. Morton (London, 1973), 134-158 (152).

${ }^{61}$ Read, Art and Industry, 43.

${ }^{62}$ For Orage's influence on Read, see: James King, The Last Modern: A Life of Herbert Read (London, 1990), 28-31; Goodway, Anarchist Seeds, 179-80.

${ }^{63}$ R.H.C., 'Readers and Writers', New Age: A Weekly Review of Politics, Literature, and Art, $22^{\text {nd }}$ March, 1917, 494-495 (494).
} 
Orage added that in treading familiar ground, Richmond's book had missed the urgent need for a novel solution. 'The doctrine of Superman, however horribly degraded and distorted it has become', he added, 'could not have arrived at its degree of popularity expect in congruity with a general desire...for a new conception of man. ${ }^{64}$ With its invocation of Nietzschean individualism and call for renewal, Orage’s passing comment on education foreshadowed many of the themes in Read's subsequent writing on aesthetic education. It is also doubtful that Read missed this discussion, partly given the fact that an evidently peeved Richmond then contributed a series of six articles to New Age adumbrating a philosophy of education one that drew heavily on the work of Sigmund Freud, an early interest of Read's, and an influence that would feature prominently in Education through Art. ${ }^{65}$ Although he never tied Orage directly to his theory of aesthetic education, given the importance of Orage's Leeds Art Club and New Age in fostering Read's intellectual growth, it is important to recognise the effect of these institutions in shaping his approach. ${ }^{66}$ Certainly, Orage’s grounding in nineteenth-century socialism and enthusiasm for Nietzsche was something Read adopted, even if he tended to describe his journey to these ideas, perhaps insincerely, as an independent one ${ }^{67}$ By the time Read came to develop his educational ideas against a backdrop of war and failed revolution, these early influences exercised a less profound

\footnotetext{
${ }^{64}$ R.H.C., 'Readers and Writers', 494.

${ }^{65}$ Kenneth Richmond, 'Education for Liberty', New Age: A Weekly Review of Politics, Literature, and Art, $3{ }^{\text {rd }}$ May, 1917, 8-9; Kenneth Richmond, 'Education for Liberty - II', New Age: A Weekly Review of Politics, Literature, and Art, $10^{\text {th }}$ May, 1917, 32-33; Kenneth Richmond, 'Education for Liberty - III', New Age: A Weekly Review of Politics, Literature, and Art, $17^{\text {th }}$ May, 1917, 55-56; Kenneth Richmond, 'Education for Liberty - IV', New Age: A Weekly Review of Politics, Literature, and Art, $24^{\text {th }}$ May, 1917, 81-82; Kenneth Richmond, 'Education for Liberty - V', New Age: A Weekly Review of Politics, Literature, and Art, $31^{\text {st }}$ May, 1917, 108-109; Kenneth Richmond, 'Education for Liberty - VI’, New Age: A Weekly Review of Politics, Literature, and Art, $7^{\text {th }}$ June, 1917, 131-132. For Freud, see: Read, Education through Art, 170-83.

${ }^{66}$ Tom Steele, 'The Leeds Art Club: A Provincial Avant-Garde?', Literature and History, Vol.14, No.1 (Spring, 1988), 91-109.

${ }^{67}$ On Orage’s influences, see: Lee Garver, 'Neither Progressive nor Reactionary: Reassessing the Cultural Politics of The New Age, The Journal of Modern Periodical Studies, Vol.2, No.1 (2011), 86-115, 96-100. For Read's explanation of his discovery of nineteenth-century socialism and Nietzsche, see: Read, Contrary Experience, 199-201, 165-167.
} 
influence, even if he still cleaved to the idea inherited from nineteenth-century socialism in the slumbering power of education.

Read confidently presented Education through Art as a solution to the barbarity of the age. Concluding his book under the provocative heading 'the necessary revolution', Read struck a stark contrast between his sedate writing environment, and the geopolitical context of the book:

Laburnum trees cast their golden rain against a hedge of vivid beech leaves. Everything is fresh and sweet in the cool early sunshine. I have just heard that...the biggest air-raid in history has taken place. Over the city of Cologne, where once we left the bones of eleven thousand martyred virgins, our airforce dropped about the same number of bombs...I listen...to the sounds that reach me here - the twittering of birds and the voices of children...in the garden... On the plains of the Ukraine two immense armies have fought to...a standstill, and now count their killed... In Libya hundreds of armoured vehicles, a triumph of human skill, manned by technicians...educated for constructive work churn through dust and torrid heat in a fury of mutual destruction. ${ }^{68}$

Rather than reveal the naked pointlessness of his book, for Read these events only highlighted the urgency of its message. Moreover, he insisted that the immense political and cultural change necessary could be achieved by relatively modest means. Instead of the revolution that he dreamt of in 1940, Read's proposal consciously eschewed any hint of compulsion implicit in conventional revolutionary strategies. ${ }^{69}$ All that the 'democratic philosopher' can do is hope to 'inspire a sufficient number of effective fellow-citizens' of the value of their plan for educational reform, and if these active citizens were organised in a 'general body of teachers and administrators' united by a common ethos, then change was tantalisingly close. Here, Read paused to condemn the conventional understanding of revolution, and foreshadow the image of 'piecemeal, non-violent, insidious and universally pervasive’ change deployed in his 1947 article:

\footnotetext{
${ }^{68}$ Read, Education through Art, 296.

${ }^{69}$ For a useful assessment of this debate, consider: Stuart White, 'Social anarchism, lifestyle anarchism, and the anarchism of Colin Ward’, Anarchist Studies, 19 (2011), 92-104 (94-97).
} 
If at first a revolution can only be guaranteed by force, by means of education it can in ten years be founded on conviction... It follows that a democratic method of education is the only guarantee of a democratic revolution: indeed, to introduce a democratic method of education is the only necessary revolution. ${ }^{70}$

This argument and its focus on stimulating the iron bonds of shared conviction as a means of displacing the state would become a central pillar of Read's thought in the years to come.

Given the clarion call for action that closed Education through Art, and given the emphasis that Read placed on the dramatic international context of the text, its political intentions seem explicit. Yet, Read remained frustrated that the book's radical message had been largely overlooked. Contributing an article to the journal Encounter in 1968 entitled 'Pragmatic Anarchism', in what was effectively Read's political testament, he reflected that:

It is not often realized how deeply anarchist in its orientation a work such as Education through Art is and was intended to be. It is of course humiliating to have to confess that its success (and it is by far the most influential book I have written) has been in spite of this fact. ${ }^{71}$

If the political pedigree of the book had been overlooked, Read's subsequent publishing history revealed that he was busily attempting to popularise its neglected social message. Perhaps most tellingly, the year after its publication by Faber \& Faber, Read condensed the three-hundred sprawling pages of Education through Art into a pithier thirty-page pamphlet for Freedom Press entitled The Education of Free Men (1944). Revising his book, Read might have realised why Education through Art had had a less dramatic impact than expected. In the words of one, otherwise glowing, review in the Times Literary Supplement: 'The book is tough reading and difficult to summarise. ${ }^{72}$ Nevertheless, Read's future career would be occupied attempting to make its message easier to summarise. In 1949 he published the collection Education for Peace, placing his vision of educational change on a starker canvas of nuclear war, and suggesting that only aesthetic education could correct the

\footnotetext{
${ }^{70}$ Read, 'Anarchism: Past and Future’, 124; Read, Education through Art, 297.

${ }^{71}$ Herbert Read, 'Pragmatic Anarchism', Encounter, XXX (Jan., 1968), 54-61 (60).

72 ‘Art and the Child: Suggested Reform in Education’, The Times Literary Supplement, 30 ${ }^{\text {th }}$ October, $1943,526$.
} 
underlying 'social neurosis' that cultivated humanity's aggressiveness and was dragging the world to the brink of disaster. This book was less well received than its predecessor, with one reviewer concluding that Read's views were anachronistic and failed to appreciate that, against a tragic midcentury, 'human wickedness must by now be considered much tougher...than....was allowed...by the hopeful seers of the 1930s. ${ }^{73}$ Undeterred, in 1955 Read appended the unequivocal subtitle A Revolutionary Policy to Education through Art in a talk delivered at University College, London. By this stage president of the Society for Education through Art, he boldly defended his use of the word 'revolutionary':

It is not a word that makes me shy...[It is] self-deception to assume that the educational reforms we advocate can be...sweetly effected....But those who have followed through the implications of this aim know that it is packed with enough dynamite to shatter the existing educational system, and to bring about a revolution in the whole structure of our society. ${ }^{74}$

The dynamite in Read's speech was not the fizzing sticks clutched by pantomime anarchists in the shadowy spaces of Victorian cities, but the explosive of shared conviction. And crucially, Read's vision remained a peaceful one that sought anarchist values but displaced insurrectionism. 'We cannot exist as disparate individuals, each a little kingdom six feet long', he wrote, but 'we must combine into societies for mutual aid...no longer suppress our fantasies, no longer deny our individuality. We are henceforth members of one another, not only in spirit, but in act. ${ }^{75}$

Read therefore remained convinced that the central message of Education through Art was pertinent, and that it offered a way to fundamentally reshape the social fabric, but what did his theory amount to? At the heart of the book was an argument that aesthetic education, by cultivating an authentic individuality in a robust communal setting, would inaugurate a new

\footnotetext{
${ }^{73}$ 'Moral Education', The Times Literary Supplement, $17^{\text {th }}$ March, 1950, 170. For an equally scathing review, see: Eric James, 'The Bomb and Education', The Manchester Guardian, $3^{\text {rd }}$ March 1950, 4.

${ }_{74}^{74}$ Herbert Read, 'Education through Art: A Revolutionary Policy’ Art Education, 8 (Nov., 1995),.3-6+16-17 (3).

${ }^{75}$ Read, 'Education through Art: A Revolutionary Policy’, 5.
} 
set of social relationships. Read saw the ideal of education as developing reciprocity between the group and the individual, and to this end commented that the 'sociological' choice before educationalists was:

Between variety and uniformity: between a conception of society as a community of persons who seek equilibrium through mutual aid: and a conception of society as a collection of people who conform as far as possible to one ideal. ${ }^{76}$

The former was Read's obvious preference, and his conception of the origin of aesthetic values led him to argue that aesthetically led education was the surest means of nurturing this balance. Ultimately, this position stemmed from his assumption that 'certain mathematical proportions give rise to that emotion in us which we normally associate with works of art', a view that supported his wider aesthetic theory. ${ }^{77}$ In Read's view then, 'a profound relation exists between the reality of art and the reality of nature', and the artist 'expresses himself with...forms discovered in nature, which...occur everywhere, and which, in the activity of art, we merely disinter, isolate and recombine. ${ }^{78}$ Except, of course, the greatest artists did not slavishly imitate nature but were engaged in dialogue with these motifs, and occasionally, in the 'most anarchic types of expressionism', the 'laws themselves are contradicted...or entirely disregarded; and a new reality is created. ${ }^{, 79}$ In reaching this conclusion, that in the 'immense and multiform' realm of nature certain 'general and universal features' exist, Read expressed a debt to the 'scholar-naturalist' D'Arcy Thompson, whose influential book On Growth and Form had been published in $1917 .^{80}$ A more profound influence, and one that sat uncomfortably with Read's libertarianism, was Plato. Read noted the authoritarian implications of Plato's ideas, but insisted that an important aesthetic principle could be

\footnotetext{
${ }^{76}$ Read, Education through Art, 4.

${ }^{77}$ Read, Education through Art, 19.

${ }^{78}$ Read, The Contrary Experience, 347; Herbert Read, The Forms of Things Unknown: Essays towards an Aesthetic Philosophy (London, 1960), 50.

${ }^{79}$ Read, The Contrary Experience, 347.

${ }^{80}$ Read, Education through Art, 16; Ruth D’Arcy Thompson, D’Arcy Wentworth Thompson: The ScholarNaturalist, 1860-1948 (London, 1958). For a brief essay on Thompson by Read, see: Herbert Read, The Tenth Muse: Essays in Criticism (London, 1957), 293-6.
} 
rescued from his thought. ${ }^{81}$ What both Thompson and Plato had suggested was the 'universality of aesthetic principle', an 'all-pervading' harmony which amounted to the 'very principle of the coherence of the universe'. ${ }^{82}$

As is clear from Read's feeling that a rejuvenated set of aesthetic values could rescue the world from oblivion, art did not figure in his schema simply as an idle pastime. With its demand for discipline and the patient contemplation of these patterns in nature, the artist was a good model for the pragmatic anarchist, something Read understood in terms of a 'positive' notion of freedom. ${ }^{83}$ Allied with this positive notion of freedom was an image of the goodlife as one in which the universality of aesthetic appreciation in humans was recognised, and individuals could freely pursue artistic endeavours, with cathartic consequences for social strife. ${ }^{84}$ Moreover, he viewed the artistic impulse as an essentially 'biological' trait and Read forcefully argued that art had been a key weapon in the evolutionary struggle for survival, ultimately underpinning the emergence of human consciousness. ${ }^{85}$ Uniting these threads, Read drew the conclusion that as aesthetics mirrored the organic harmony of nature, aesthetic education could cultivate moral poise and equanimity:

The aim of imaginative education has been...described by Plato: it is to give the individual a concrete sensuous awareness of the harmony and rhythm which enter into the constitution of all living bodies... which is the formal basis of all works of art, to the end that the child in its life and activities, shall partake of the same organic grace and beauty. ${ }^{86}$

The radical thrust of Read's message, and its basis as a potentially regenerative set of ideas, was that aesthetic education could stimulate new social relationships, by challenging the

\footnotetext{
${ }^{81}$ Read, The Education of Free Men, 11.

${ }^{82}$ Read, Education through Art, 65.

${ }^{83}$ Read, Education through Art, 6.

${ }^{84}$ Read, Education through Art, 302,6.

${ }^{85}$ Herbert Read, Anarchy \& Order: Essays in Politics (London, 1953), 220. For art as the basis of human consciousness, see: Herbert Read, Icon \& Idea: The Function of Art in the Development of the Human Consciousness (New York, 1955).

${ }^{86}$ Read, Education through Art, 70.
} 
conventional modes of human interaction. Reflecting his anarchist commitments, central to this vision was the argument that these novel relationships would be non-hierarchical, and that this 'mutual aid' ethos would serve as the crucible for an authentic individuality to develop. ${ }^{87}$ With this in mind, Read gives considerable space to the discussion of the 'teacher and the child', and outlined the basis of a productive relationship:

He will...establish a relationship of reciprocity and trust between himself and the pupil, and one of co-operation and mutual aid between all the individuals within his care...What is required is the give and take of a mutual relationship...The child is likely to develop his side of the relationship in the natural course of his development: from the teacher a more deliberate approach will be necessary. ${ }^{88}$

In Education through Art, Read framed the discussion of the teacher/pupil relationship in the context of an analysis of the work of Buber, a figure who would exercise an important influence on the generation of anarchists represented by Ward. ${ }^{89}$ Drawing on Buber's ‘characteristic mysticism', Read argued that carving a niche for ‘creativity’ alone is insufficient, and instead the ‘instinct for union’ must be recognised as a precondition of finding pleasure in the act of creation. In other words, whilst 'all educators recognize the necessity of not repressing spontaneity...they leave the child beating his wings in the void'. This sense of 'reciprocity’ supports Read's conception of freedom, which he characterised as 'not an end in itself', but 'a path...not a dwelling place' ${ }^{90}$ Read's definition of freedom and his precepts for encouraging the creative sensibility of the child therefore dovetail; both rest on the assumption that meaningful liberty and individual self-development are only attainable in a social context. Aesthetic education, in Read's view, is the means for attaining this uncoerced unity. Invoking Plato, Read noted that he recognised the truth of the maxim that aesthetics had an essentially moralising effect, both in the contemplation of universal forms,

\footnotetext{
${ }^{87}$ Herbert Read, The Cult of Sincerity (London, 1968), 90, 91. See also: Read, “Pragmatic Anarchism”, 60-61.

${ }^{88}$ Read, Education through Art, 23

${ }^{89}$ For Read on Buber’s influence, see: ‘A Conversation with Herbert Read', Art Education, 20 (Dec., 1967), $32-$ 5 (34). For Ward on Buber, see: Colin Ward, Influences: Voices of Creative Dissent (London, 1992), 88-90.

${ }^{90}$ Read, Education through Art, 282.
} 
and in the discipline cultivated in artistic practice. 'True discipline is a spontaneously evolved pattern of behaviour', Read wrote, and 'aesthetic education...brings grace to the body and nobility to the mind...and we must make art the basis of education because it can operate in childhood, during the sleep of reason...when reason does come, art will have prepared a path for her. ${ }^{91}$

Read's debt to Buber, and his feeling that the 'I-Thou dialogue' was an aspect of a broader mutual aid tendency, is an important feature of his thought, but more significant is the fact that this reading of Buber represents a reorientation of Read's anarchism. ${ }^{92}$ Furthermore, given Buber's clear debt to Landauer's anarchism, it shows that Read's anarchism was drawing inspiration from fresh sources. For Buber, writing in his influential 'genetic' account of the utopian imagination in socialist thought, Paths in Utopia (1949), Landauer's major contribution was his 'direct insight into the nature of the State'. Recognising that today 'men stand to one another...in a “statual” relationship', Landauer’s work marked a step beyond Kropotkin's commonplace perception of revolution, as did his insistence that the spiritual life of post-capitalist society was an important concern for the revolutionary. ${ }^{93}$ Read was influenced by this rereading of revolution, but was equally drawn to the idea that a spiritual connection between individuals, something he termed ‘communion’ following Buber, was an important aspect of communalist society towards which socialist theory had traditionally been insensitive. ${ }^{94}$ To Read, the great value of Buber's I-Thou dialogue lay in its recognition of the importance of an individuality that was rooted in a defined sense of community. Instead of freedom being the opposing pole of compulsion, Read argued that it was

\footnotetext{
${ }^{91}$ Read, Education through Art, 277.

92 Herbert Read, The Tenth Muse: Essays in Criticism (London, 1957), 96.

${ }^{93}$ Martin Buber, Paths in Utopia (London, 1949), N.P, 46,53.

${ }^{94}$ Herbert Read, Existentialism, Marxism and Anarchism (London, 1949), 27.
} 
communion; a purposeful liberty secured in the context of strong social bonds. ${ }^{95}$ While this sense of communal individuality was a discernible feature of the historical anarchist tradition, in Read's rendering it lay closer to his Nietzschean defence of the individual. ${ }^{96}$ Although prone to express this in the elitist terms of 'the superman' holding 'himself aloof from the group', Read's understanding of artistic creativity rested on a dialectical understanding of the relationship between the individual and the community. ${ }^{97}$ In Read's thought, the I-Thou dialogue, and his interest in Nietzschean affirmation, represented a conception of individual social relations as perpetually fraught, but gaining their value and creativity from this very dynamic.

In another sense, Read's reading of Buber denotes a highly intellectualised politics, in which developing a sophisticated philosophy responding to parallel intellectual trends was seen as a worthy endeavour. Perhaps inevitably, not all anarchists appreciated this shift from the street to the study, and Read was often on the receiving end of bitter vituperation from those believing that he had lost sight of what anarchism meant in the first place. ${ }^{98}$ More significant than this, however, is Read's emphasis on personal change as a prerequisite for searching social change. Instead of a fixation on the moment of revolutionary cataclysm, his thought after the war centred on a concern with developing a robust notion of freedom in which individuality is privileged. Although visible in the shibboleths that he inherited from Kropotkin, Read placed particular emphasis on how this rejuvenated subjectivity would itself

\footnotetext{
${ }^{95}$ Read, Existentialism, Marxism and Anarchism, 27. I explore this theme in more depth in: Matthew S. Adams: “'As harmless as the rats and crows': Religion and Spirituality in Herbert Read's Anarchism', in Essays in Anarchism and Religion, edited by Alexandre Christoyannopoulous and Matthew S. Adams - forthcoming. ${ }^{96}$ On communal individuality, see: Alan Ritter, Anarchism: a Theoretical Analysis (Cambridge, 1980).

${ }^{97}$ Read, Philosophy of Anarchism, 13; Read, Politics of the Unpolitical, 160.

${ }^{98}$ Consider: Stuart Christie, Granny Made Me an Anarchist (London, 2004); Stuart Christie and Albert Meltzer, The Floodgates of Anarchy (London, 1972), 154; Albert Meltzer, I Couldn't Paint Golden Angels: Sixty Years of Commonplace Life and Anarchist Agitation (Edinburgh, 1996), 126; Vernon Richards, Protest Without Illusions (London, 1981), 82.
} 
force social change. ${ }^{99}$ In Education through Art, and the books and articles that followed, Read's focus was on the formation of the revolutionary subject whose actions, by contracting novel relationships cultivated by an aesthetic education, leads to a definitively different kind of society. He predated the popularisation of the term 'prefigurative politics', conceived as 'present-tense experimentation' or the desire 'realize anarchist social relations within...existing society', but it is difficult to see how Read's definition of effective action as 'personal, cellular, local, I would say...molecular' does not echo this discourse. ${ }^{100}$ This focus, and the fact that Landauer's work remained largely unavailable in English until the 1970s, belies the reading that sees in Landauer the cause of an intellectual foment that induced an intellectual reorientation of British anarchism. ${ }^{101}$ Against the backdrop of war, as his attitudes towards violence underwent revision, and the outrage that produced the Freedom Defence Committee fizzled out into apathy, Read reconceptualised how anarchism might be achieved. Education was the key, and the opportunity it presented to remodel social relations without the sanguinary catharsis imagined by the nineteenth-century pioneers of anarchism was appealing. Coupled with his aesthetics, that emphasised the universality of aesthetic values and the inherently moralising effect of creative activity, Read believed that he had discovered a new path to anarchy.

\footnotetext{
${ }^{99}$ Matthew S. Adams, “'The Truth of a Few Simple Ideas’: Peter Kropotkin, Herbert Read and the Tradition of Anarchist-Communism in Britain, 1886-1968' (University of Manchester, Ph.D. thesis, 2011).

${ }^{100}$ Uri Gordon, 'Anarchism Reloaded', Journal of Political Ideologies, 12 (2007), 29-48 (40, 36); The italics are Read's own: Herbert Read, Education for Peace (London, 1949), 56. The term was first used in 1982 by Wini Breines in her book on the American New Left, see: Wini Breines, Community and Organization in the New Left: 1962-1968: The Great Refusal (New York, 1982), 6.

${ }^{101}$ Landauer's short piece on Social Democracy printed under the auspices of The Torch is an exception. See: Gustave (sic) Landauer, Social Democracy in Germany (London, N.D. [circa 1896]). Aside from this, the main biographies date from the 1970s, see: Ruth Link-Salinger Hyman, Gustav Landauer: Philosopher of Utopia (Indianapolis, ID, 1977); Lunn, Prophet of Community; Charles B. Maurer, Call to Revolution: the Mystical Anarchism of Gustav Landauer (Detroit, MI, 1971). Landauer's own work was only made available with Gustav Landauer, For Socialism trans. David J. Parent (St. Louis, MO, 1978). This lacuna was recently partly filled: Gustav Landauer, Revolution and Other Writings: A Political Reader trans. Gabriel Kuhn (Oakland, CA, 2010). Colin Ward made this point about the meager coverage of Landauer's thought in English, see: C.W. 'Gustav Landauer', 244.
} 


\section{Conclusion: Read in Anarchist History, Read in Intellectual History}

Education through Art grew from a fundamental reassessment of revolutionary tactics that reflected Read's own developing dissatisfaction with conventional praxis. Placing these ideas in the context of Read's emerging hostility to violence, itself influenced by his vacillating position on the legitimacy of war, throws the significance of his educational theory into sharper relief. His post-war rejection of revolutionary violence, and his feeling that the opportunity for a 'British revolution' had been lost, reflect a position that Read ultimately began to reach during the war, and one that Education through Art defined. This position solidified once the war ended, and the aftermath of the conviction of the Freedom anarchists revealed the enduring power of the state. The initial enthusiasm that drove the Freedom Defence Committee forward petered-out quickly, and Read's disappointment, and feeling that this represented a more general malaise on the left, reaffirmed his opinion that conventional understandings of revolution must be rethought. It may have been appropriate for the broken states of central Europe to retain their guns, but in Britain, a different approach was needed. The context of Read's educational ideas is therefore crucial to comprehending their intention as a contribution to a debate emerging specifically from anarchist politics, but this story is by no means a straightforward one. Read's opposition to violence, so frequently highlighted as a defining aspect of his political project, was inconsistent. Although generally maintaining a principled opposition to war, he ended up revising his view on the Second World War, and his eventual pacifist rejection of violence began to emerge, confusingly, in the midst of supporting the Allied war effort. Yet by the end of the conflict, Read had reached a position that he would maintain until his death in 1968, and, in Education through Art, make an important and foresighted contribution to anarchist theory. 
Conventionally, Read has occupied a relatively marginal place in the narrative of British anarchism, but the reading of his work here, challenges this position. His educational works may be deeply problematic - prolix, obscure, and overly ambitious - but his attempt to fuse educational, aesthetic, and revolutionary principles reveals a rich intellect at work. This alone confounds the interpretation that Read's primary achievement was in keeping the embers of the 'classical' anarchist tradition glowing, before more able theorists, such as Colin Ward and Murray Bookchin, arrived to ignite anarchism with their 'originative’ politics. ${ }^{102}$ Read's politics were subtler than this, and amounted to an intellectually demanding mix of aesthetics, continental philosophy, and radical politics, that can only be understood in the context of 1930s and 1940s intellectual life. Read's social philosophy grew in an intellectual atmosphere where the pastoral reaction to the Great War and urbanism - the 'avalanche of the “unmodern”” - confronted the radical aesthetics of émigré modernism. ${ }^{103}$ His politics echo this tension; between Read's self-proclaimed 'peasant' origins, and the modish cosmopolitanism of the cultural world he inhabited. ${ }^{104}$ The result is an often ambiguous, but persistently fascinating political project, whose separate strands come into view when Read's call for art education is placed in the context of his social ideas. A romantic inheritance looms large in Read's thought, from the premise of his educational theory that yearned for individual assertion and self-becoming, to the basis of his aesthetics that saw the perceptive artist engaged in a dialogue with patterns inherent in nature. Indeed, the very heart of his anarchist vision - that of self-supporting groups practising mutual aid, echoes the localism emerging in the face of the ever widening boundaries of the city. It is perhaps no surprise that Read, corresponding with Woodcock who was busily building a house in the Canadian wilds,

\footnotetext{
${ }^{102}$ For this narrative, see: Woodcock, Anarchism (1986), 420; Goodway, Anarchist Seeds, 189.

103 Jay Winter, Sites of Memory, Sites of Mourning: The Great War in European Cultural History (Cambridge, 1995), 54.

${ }^{104}$ Read, Poetry and Anarchism, 16. Read's eventual dissatisfaction with London life and return to his native Yorkshire is indicative of this tension. For a useful discussion of this see: King, The Last Modern.
} 
confessed that 'Walden was always one of my favourite books. ${ }^{105}$ Much of this Read took from the anarchist tradition, an inheritance reflected through the lens of the intellectual fashions of the age; and yet, his politics was more than this. He did not simply reassert adages that had seemed appropriate in the Victorian era, but endeavoured to fuse his cultural interests with anarchist theory. Art would become a means to produce the kind of citizens that would make an anarchist society work, and the diffusion of artistic values would be the means of measuring its success.

This assessment of Read's work questions his eclipse from British intellectual history in general, and anarchist history in particular, but aside from being a thinker worth reading purely for his idiosyncrasies, Read's importance lies in his contribution to pragmatic anarchism. That Ward and Bookchin should praise Read for his farsighted, if inconsistent, political writing should make it clear that his currently minor role in the history of British anarchism does not suitably reflect this period in anarchism’s intellectual history. ${ }^{106}$ Focusing on Education through Art and Read's attempts to rethink revolutionary change, shows that he was dealing with the issues with which the thinkers in the 1960s would grapple. More than this, however, they were working in a seam of thought that Read helped create, define, and popularise. Landauer's aphorism that the state was a relationship rather than an entity might have been frequently inscribed on the pages of Ward's Anarchy, but this saturation hints at a generally scant knowledge of Landauer's politics. Indeed, on a practical level, Ward admitted that it was through Read that he became familiar with the tradition of libertarian socialism, with its mysticism and romanticist origins, associated with Landauer and Buber. ${ }^{107}$ The fact

\footnotetext{
${ }^{105}$ Herbert Read to George Woodcock, 15 ${ }^{\text {th }}$ April 1950, Herbert Read Archive, University of Victoria, 10. ${ }^{106}$ For Bookchin's comments on Read, see: Murray Bookchin, 'Deep Ecology, Anarchosyndicalism, and the Future of Anarchist Thought', Deep Ecology \& Anarchism: A Polemic (London, 1997), 47-58; Murray Bookchin, 'The Postwar Period', Anarchism, Marxism, and the Future of the Left: Interviews and Essays: 1993-1998 (Edinburgh, 1999), 44-58 (57); Murray Bookchin, Post-Scarcity Anarchism (Edinburgh, 2004$), 36$. ${ }^{107}$ Ward, Influences, 79. For Read's early use of Buber, alongside Education through Art, consider: Herbert Read, Existentialism, Marxism and Anarchism (London, 1949), 27.
} 
that Landauer was not the subject of serious scholarly attention until the 1970s, and that most of his work remains unavailable in translation, suggests that his influence has been overstated. With this in view, to understand the 'pragmatic' turn in anarchism, it is necessary to look closer to home. And whilst the tightly packed pages of Education through Art and its unwieldy philosophical baggage might seem far from 'pragmatic', it is clear that the assumptions that informed the later reassessment of anarchist tactics were central to Read's vision. He too looked to the local and rejected the apocalyptic; he also thought that forming new relationships was the surest way to destroy the state; and he baulked at the more lurid proclamations of anarchism's revolutionary past. As Read sat writing Education through Art as the laburnum trees rustled in the breeze and he digested the news of the latest horrors of the mechanised warfare in the East, he voiced an outcry against this fate, and in doing so, planted the seeds of a 'renaissance' of anarchist thinking.

\section{Acknowledgements}

An early version of this paper was presented at the workshop 'Alternative Education(s):

Education and the Left' at the University of Manchester in November 2011, and I am grateful to the participants for their comments, and the organiser, Edward Poole, for reading a draft of this article. Thank you also to, Professors Stuart Jones and Martin Adams, and Dr Catherine Feely, for their comments on this paper. 